Bangladesh J. Pl. Breed. Genet., 26(2): 33-38, 2013

\title{
CHARACTER ASSOCIATION OF SOYBEAN (Glycine max) LINES FOR YIELD CONTRIBUTING TRAITS
}

\author{
A. K. M. S. Islam and P. K. Rai ${ }^{1}$ \\ Hybrid Rice Research Division \\ BRAC Agricultural Research and Development Centre \\ Gazipur 1701, Bangladesh.
}

\begin{abstract}
The present study was conducted with ten soybean genotype on correlation, path coefficient and genetic component of some important traits. Ten characters were studied to find out the suitable traits for the improvement of soybean yield. It was observed that yield per plot was positively correlated with pods per plant, seeds per pod, branches per plant, harvest index, days to maturity and plant height which revealed that selection based on these traits could significantly improved the grain yield of soybean. From the path coefficient analysis, it was observed that among the different yield contributing characters pods per plant, seeds per pod, plant height, 100 seed weight contributed maximum direct positive effect to yield per plot. Negative direct effect was observed for days to flowering and days to maturity, but its correlation with yield was positive. It was due to its positive indirect effect. The residual effect was found 0.175 which indicated that $82.50 \%$ of the variability was accounted for 10 yield and yield contributing traits included in the present study. Rest $17.50 \%$ variability might be controlled by other yield contributed traits that was not included in the present investigation.
\end{abstract}

Keywords: Correlation; path analysis; soybean; yield; Glycine max L.

\section{INTRODUCTION}

Soybean (Glycine $\max$ L. Meril) is the world's most important oil producing grain legume crop in terms of total production and international trade. The crop is grown throughout the world accounts for approximately $50 \%$ of the total production of oil seed crops in the world. The largest soybean producing countries are: The USA, Brazil, Argentina, Mexico, China and Indonesia. The acreage of soybean in Bangladesh is around 22,000 acre and production was 6000 metric tons in the year of 2008-09 (BBS, 2010). With the growth of population, Bangladesh needs more protein, fat and minerals. But our protein source is limited. Soybean can play a significant role in providing protein support. Soybean can be grown, as a source of protein and of oil crops as well as has become a cash crop in our country. Information on correlation coefficient between yield and its contributing characters has always been helpful as a basis for selection for yield in a breeding programme. Thus determination of correlation between the characters are a matter of considerable importance in selection practices since it helps in construction of selection indices also permit the prediction of correlated response. Following correlation analysis, the path coefficient analysis provides a true picture of genetic association

\footnotetext{
${ }^{1}$ Department of Genetics and Plant Breeding, Bangabandhu Sheikh Mujibur Rahman Agricultural University, Gazipur 1706, Bangladesh.
} 
between different traits. Path coefficient analysis specificies the cause and effect, and measures their relative importance. Therefore, correlation with the path coefficient analysis quantifies the direct and indirect contribution of one character upon another. Considering these facts, the present study was conducted with 10 soybean genotypes to observe the nature of relationship of different morphological characters and yield attributes among themselves and to estimate the direct and indirect effects of important characters on yield through co-efficient analysis.

\section{MATERIALS AND METHODS}

Ten soybean genotypes [AVRDC-14(SI-4), AVRDC-62(SI-14), AVRDC-73(SI11), AVRDC-78(SI-01), Sohag, BAU-S/70, BAU-S/80, BARI Soybean-5, BAU-S/109, BAU-S/147] were grown in randomized complete block design (RCBD) with three replications during Rabi 2011. Plot size was $4 \mathrm{~m} \times 2.5 \mathrm{~m}$, block to block $1 \mathrm{~m}$, plot to plot $60 \mathrm{~cm}$, line to line $30 \mathrm{~cm}$ and plant to plant $5-7 \mathrm{~cm}$ distance were maintained. Urea, TSP and MP were applied @ 60-150-70 kg/ha respectively, and rhizobium inoculants $25 \mathrm{~g} / \mathrm{kg}$ seed recommended for soybean cultivation. The seeds were sown in continuous rows keeping the row-to-row distance of $30 \mathrm{~cm}$. Normal intercultural practices and plant protection measures were followed to raise the crop successfully. Crop was successfully harvested. Total plot was harvested for measuring grain yield. Data were collected from 10 randomly selected pods of each genotype. Data were recorded on days to flowering, days to maturity, plant height, branches per plant, pods per plant, seeds per pod, 100 seed weight, flowers per plant, pod setting efficiency, yield per plot and harvest index. All data obtained from each trait were statistically analyzed. The genotypic and phenotypic correlation was estimated by the formula suggested by Miller et al. (1958). Path coefficient analysis was done according to Wright (1921) and Dewey and Lu (1959).

\section{RESULTS AND DISCUSSION}

Relationship between yield and yield contributing characters including growth index were studied using genotypic and phenotypic correlation coefficient (Table 1). Yield per plot was positively correlated with days to maturity, plant height, branches per plant, pods per plant, seeds per pod, 100 seed weight, flowers per plant, harvest index and pod setting efficiently. In this study, it was found that plant height had significantly positive correlation with pods per plant and flowers per plant. At the same time negative correlation with seeds per pod suggesting increasing plant height will decrease the seeds per pod. This is in confirmation with the results as stated by Dogney et al. (1998). Branches per plant showed significantly positive correlation with yield per pods and positive correlation with pods per plant, seeds per pod and flowers per plant. Pods per plant gave highly positive significant with flowers per plants, pod setting efficiency and plot yield. That suggesting that plant having more number of pods proportionately increases the yield. Saka et al. (1996) observed that the number of pods per plant was significantly correlations with flowers per plants and plot yield. Seeds per pod showed positive correlation with harvest index and negative correlation with flowers per plant. It indicating increasing the number of flowers per plant will decrease the seeds per pod. According to Singh et al. (1995), number of seeds per plot showed negative association with the flowers per plant. 100 seed weight had positive correlation with flowers per plant, harvest index, pod setting efficiency and plot yield. Flowers per plant showed highly positive significant with plot yield and pod setting efficiency. Harvest index showed significantly positive correlation with pod setting efficiency. 
Table 1. Phenotypic $\left(r_{\mathrm{p}}\right)$ and genotypic $\left(\mathrm{r}_{\mathrm{g}}\right.$ correlation coefficients between yield and yield contributing characters in soybean

\begin{tabular}{|c|c|c|c|c|c|c|c|c|c|c|c|}
\hline Characters & & $\begin{array}{l}\text { Days to } \\
\text { maturity }\end{array}$ & $\begin{array}{c}\text { Plant height } \\
(\mathrm{cm})\end{array}$ & Br/Plant & Pods/plant & $\begin{array}{c}\text { Seeds } \\
\text { /pod }\end{array}$ & $\begin{array}{c}100 \text { seed } \\
\text { wt. }\end{array}$ & \begin{tabular}{|c|} 
Flowers/ \\
plant
\end{tabular} & $\begin{array}{c}\text { Harvest } \\
\text { index }\end{array}$ & $\begin{array}{c}\text { Pod setting } \\
\text { efficiency }\end{array}$ & Plot yield \\
\hline \multirow{2}{*}{ Days to flowering } & $r_{p}$ & $0.90 * *$ & $0.84 *$ & 0.56 & $0.81 * *$ & -0.03 & 0.52 & $0.81 * *$ & 0.25 & 0.48 & 0.68 \\
\hline & $r_{g}$ & $0.81 * *$ & $0.74 *$ & 0.47 & $0.77 * *$ & -0.01 & 0.30 & $0.78^{* *}$ & 0.20 & 0.43 & 0.63 \\
\hline \multirow[t]{2}{*}{ Days to maturity } & $\mathrm{r}_{\mathrm{p}}$ & & 0.39 & 0.45 & 0.47 & 0.24 & -0.03 & 0.39 & 0.07 & 0.05 & 0.41 \\
\hline & $r_{g}$ & & 0.33 & 0.41 & 0.45 & 0.21 & -0.01 & 0.37 & 0.04 & 0.03 & 0.39 \\
\hline \multirow[t]{2}{*}{ Plant height $(\mathrm{cm})$} & $r_{p}$ & & & 0.49 & $0.69 *$ & -0.26 & 0.27 & $0.75^{*}$ & 0.14 & 0.59 & 0.54 \\
\hline & $r_{g}$ & & & 0.47 & $0.65^{*}$ & -0.23 & 0.25 & $0.73^{*}$ & 0.11 & 0.57 & 0.51 \\
\hline \multirow[t]{2}{*}{$\mathrm{Br} / \mathrm{Plant}$} & $r_{p}$ & & & & 0.65 & 0.24 & -0.27 & 0.65 & 0.04 & 0.29 & $0.67 *$ \\
\hline & $r_{g}$ & & & & 0.63 & 0.21 & -0.27 & 0.63 & 0.02 & 0.27 & $0.65^{*}$ \\
\hline \multirow[t]{2}{*}{ Pods/plant } & $r_{p}$ & & & & & 0.30 & 0.45 & $0.98^{* *}$ & 0.62 & $0.82 * *$ & $0.99 * *$ \\
\hline & $r_{g}$ & & & & & 0.23 & 0.38 & $0.93 * *$ & 0.58 & $0.78 * *$ & $0.94 * *$ \\
\hline \multirow[t]{2}{*}{ Seeds/pod } & $r_{p}$ & & & & & & 0.28 & -0.13 & $0.71 *$ & 0.38 & 0.53 \\
\hline & $r_{g}$ & & & & & & 0.26 & -0.11 & $0.69 *$ & 0.35 & 0.51 \\
\hline \multirow[t]{2}{*}{100 seed wt. } & $r_{p}$ & & & & & & & 0.31 & $0.71 *$ & $0.71 *$ & 0.44 \\
\hline & $r_{g}$ & & & & & & & 0.28 & $0.70^{*}$ & $0.69 *$ & 0.42 \\
\hline \multirow[t]{2}{*}{ Flowers/ plant } & $\mathrm{r}_{\mathrm{p}}$ & & & & & & & & 0.42 & $0.77 *$ & $0.91 * *$ \\
\hline & $r_{g}$ & & & & & & & & 0.32 & $0.65 *$ & $0.78 * *$ \\
\hline \multirow[t]{2}{*}{ Harvest index } & $r_{p}$ & & & & & & & & & $0.84 * *$ & $0.71 *$ \\
\hline & $r_{g}$ & & & & & & & & & $0.83 * *$ & $0.70 *$ \\
\hline \multirow[t]{2}{*}{ Pod setting efficiency } & $r_{p}$ & & & & & & & & & & $0.83 * *$ \\
\hline & $r_{g}$ & & & & & & & & & & $0.81 * *$ \\
\hline
\end{tabular}

$*=$ Significant at $5 \%$ level, $* *=$ Significant at $1 \%$ level 
Table 2. Partitioning of genotypic correlation into direct effect (bold) and indirect effect of different yield contributing characters on the yield in soybean genotypes

\begin{tabular}{|c|c|c|c|c|c|c|c|c|c|}
\hline Characters & $\begin{array}{l}\text { Days to } \\
\text { flowering }\end{array}$ & $\begin{array}{l}\text { Days to } \\
\text { maturity }\end{array}$ & $\begin{array}{c}\text { Plant height } \\
(\mathrm{cm})\end{array}$ & Pods/plant & Seeds/pod & 100 seed wt. & $\begin{array}{l}\text { Flowers/ } \\
\text { plant }\end{array}$ & $\begin{array}{l}\text { Pod setting } \\
\text { efficiency }\end{array}$ & Plot/ yield \\
\hline Days to flowering & -0.2271 & -0.0490 & 0.1395 & 0.8223 & -0.0051 & 0.0381 & 0.0317 & -0.1245 & 0.626 \\
\hline Days to maturity & -0.1841 & -0.0604 & 0.0624 & 0.4803 & 0.0832 & -0.0008 & 0.0152 & -0.0078 & 0.388 \\
\hline Plant height $(\mathrm{cm})$ & -0.1669 & -0.0199 & 0.1898 & 0.6980 & -0.0879 & 0.0322 & 0.0299 & -0.1652 & 0.510 \\
\hline Pods/plant & -0.1742 & -0.2708 & 0.1236 & 1.0721 & 0.0902 & 0.0477 & 0.0378 & -0.2261 & 0.944 \\
\hline Seeds/pod & 0.0030 & -0.0129 & -0.0427 & 0.2477 & 0.3907 & 0.0328 & -0.0043 & -0.1022 & 0.512 \\
\hline 100 seed wt. & -0.0681 & 0.0036 & 0.0480 & 0.4020 & 0.1008 & 0.1271 & 0.0112 & -0.1994 & 0.422 \\
\hline Flowers/plant & -0.1767 & -0.0225 & 0.1393 & 0.9928 & -0.0414 & 0.0350 & 0.0408 & -0.1872 & 0.780 \\
\hline $\begin{array}{l}\text { Pod setting } \\
\text { efficiency }\end{array}$ & -0.0097 & -0.0016 & 0.1080 & 0.8352 & 0.1375 & 0.0873 & 0.0263 & -0.2903 & 0.805 \\
\hline
\end{tabular}

Residual effect: 0.175 
All this result suggest that the number of pods per plant, harvest index, seeds per pod, branches per plant and days to maturity are important yield contributing characters and addressed to be in the selection criteria for soybean. In order to find a clear picture of the interrelationship between seed yield and their yield contributing character, direct and indirect effects were worked out using path coefficients. The results of the path coefficients are presented in Table 2. The results of path coefficient analysis revealed that pods per plant had the highest direct effect (1.0721) on grain yield per plot followed by seeds per pod (0.3907), 100 seed weight (0.1271) and plant height $(0.1898)$. Such results indicated that direct selection based on these characters would be effective for yield improvement of soybean. Flowers per plant (0.264) showed positive and negligible direct effect on yield. The positive indirect effect via plant height $(0.1393)$, pods per plant (0.9928), 100 seed weight $(0.0350)$ made the total correlation positive and significant on yield $(0.780)$. Number of pods per plant had high positive direct effect $(0.1898)$ on grain yield. It has positive indirect effect via plant height $(0.1236)$, seeds per pod (0.0902) and 100 seed weight (0.0477). It showed negative indirect effect via days to flowering (-0.1742), days to maturity (-0. 278) and pod setting efficiency $(-0.2261)$. However, overall, it produced positive effect on yield. Major et al. (1996) noticed that pods per plant had direct and positive effects on grain yield. Days to maturity had negative direct effect to yield $(-0.0604)$ but strong positive effect of plant height (0.0624), pods per plant (0.4803) and seeds per pod (0.0832) made total positive effect on yield. Chettri et al. (2003) showed that days to maturity positively influenced grain yield. Similar results were found by Raut et al. (2001). Plant height registered considerable positive direct effect $(0.1898)$ on yield per plot. It also had positive indirect effect via pods per plant (0.6980), 100 seed weight $(0.0322)$, and flowers per plant (0.0299). However, it showed negative indirect effect via days to maturity $(-0.1669)$, pod setting efficiency $(-0.1652)$, seeds per pod (-0.0879) and the total correlation between plant height and plot yield was highly positive and significant (0.510). Sridhara et al. (1998) observed that the plant height and number of pods per plant seemed to be significant contributors to seed yield.

Days to flowering had negative direct effect (-0. 2271) on plot yield. It also has positive indirect effect on yield via plant height $(0.1395)$, pods per plant $(0.8223)$ and the total correlation on yield was positive. Chamundeswari and Aher (2003) recorded a negative correlation between days to flowering and plot yield. Seeds per pod had highly positive direct effect $(0.3907)$ on seed yield. It had negative effect via days to maturity ($0.0129)$, flowers per plant $(-0.0043)$ on seed yield and the total correlation was positive (0.512). Due to highly positive indirect effect via pods per plant and 1000 seed weight. Pod setting efficiency had highly negative (-0.2903) direct effect on seed yield. Pod setting efficiency had negative indirect effect via days to flowering (-0.0097), days to maturity (-0.0016). On the other side positive indirect effect such as plant height $(0.1080)$, pods per plant $(0.8352)$, seeds per pod $(0.1375), 100$ seed weight $(0.0873)$ and flowers per plant (0.0408) made total effect positive on plot yield. From the path coefficient analysis, it was observed that among the different yield contributing characters pods per plant, seeds per pod, plant height $(\mathrm{cm})$ and 1000 seed weight contributed maximum direct positive effect to yield per plant. Therefore, it may be concluded that there is scope for improving yield in soybean through direct selection of these characters. The residual effect was found 0.175 which indicated that $82.50 \%$ of the variability was accounted for ten yield and yield contributing traits included in the present study. Rest $17.50 \%$ variability might be controlled by other yield contributed traits that was not included in the present investigation. 


\section{REFERENCES}

BBS. 2010. Monthly Statistical Bulletin, Bangladesh Bureau of Statistics, Bangladesh.

Chamundeswari, N and R. P. Aher. 2003. Characters association and component analysis in soybean (Glycine max L. Merill). Mahatma Phule Krishi Vidyapeth. Ahmed Nagar, India. 19:2, 199-203.

Chettri, M., S. Mondol and R. Nath. 2003. Studies on correlation and path analysis in soybean (Glycine $\max$ L. Merill) in the Darjelling hills J.Hill Res. Bidhan Chandra Krishi Viswavidyalaya, India. 16(2): 101-103.

Dewey, D. R and K. H. Lu. 1959. A correlation and path coefficient analysis of components of creasted wheat grass seed production. Agron. J. 51: 512-518.

Dogney, M. L., V. K. Gour and A. K. Mchta. 1998. Path coefficient analysis of yields attributing characters in back cross population of soybean (Glycine $\max \times G$. soja) $\times$ Glycine max L. Merrill. Crop Res. Hisar. 16(3): 325-357.

Major, S., S. Gyanendra, M. Singh and G. Singh. 1996. Assessment of genetic variability, correlation and path analysis in soybean (Glycine max L. Merill) under mid hills in sikkim. J. of Hill Res. 9(1): 150-152.

Miller, P. A., J. C. Williams, H. F. Robinson and R. E. Comstok. 1958. Estimates of genetic and environmental variance and covariance and their implication in selection, agron. J. 50: 126-131.

Raut, P. B., N. N. Koltre, T. H. Rathod, R. S. Shivankar and Patil. 2001. Correlation and path coefficient analysis of yield and its components in soybean (Glycine max, L. Merill). Annals of Plant Phy. 15(1): 58-62.

Saka, K., E. R. Shipe and S. U. Wallace. 1996. Relationship among plant characters in soybean with different seed size. Soybean Genet. News. 23: 225-229.

Singh, I., P. S. Phul, G. R. P. Singh and S. R. Sharma. 1995. Genetic variability and response of soybean genotypes to Bradyrhizobium japonicum inoculation. J. of Res. Panjab Agril. Univ. 32(2): 245-252.

Sridhara, S., S. Thimmegowda and M. V. Chalapathi. 1998. Yield structure analysis in soybean (Glycine max L. Merill). Indian agriculturists, 42(2): 81-87.

Wright, S. 1921. Correlation and causation. J. Agric. Res. 20: 557-587. 